\title{
The decline of Falkland Islands penguins in the presence of a commercial fishing industry
}

\author{
La disminución de los pingüinos de las Islas Falklands en la presencia de actividades \\ de pesca comercial
}

\author{
MIKE BINGHAM \\ Environmental Research Unit, P.O. Box 434, Stanley, Falkland Islands; \\ e-mail: conservation@falklands.net
}

\begin{abstract}
The Falkland Islands are an important breeding site for three species of penguin, gentoo (Pygoscelis papua), southern rockhopper (Eudyptes c. chrysocome) and Magellanic penguin (Spheniscus magellanicus). The total penguin population for the Falkland Islands has declined by $84 \%$ during the 1980s and 1990s. These declines did not occur in coastal South America, so potential causes of decline in the Falklands have been investigated. The suspected cause of decline is a reduction of fish and squid due to large-scale commercial fishing around the Falklands. Since 1995 rockhopper and gentoo populations have ceased declining, and appear to have reached a new equilibrium, albeit at a much lower level than before commercial fishing began. This has been matched by improved chick-rearing success and juvenile survival, however Magellanic penguins continue declining in the Falklands. Diet analysis shows that Magellanic penguins have a greater reliance on squid and fish species being taken commercially. In 1998 drilling for oil began around the Falklands, despite warnings that environmental protection was inadequate. Within a month the first of three separate oil spills occurred, killing and contaminating hundreds of penguins. The oil rig completed its drilling operations after five months and left the Falklands. Since then no further oil spills have occurred. Oil exploration is due to recommence in the near future, and environmental safeguards have not been improved. Ecotourism has increased rapidly over recent years in the Falklands, with penguins being the main attraction. Monitoring of the affects of tourism has concentrated on breeding success and population change, and the results indicate no detrimental affects on penguin populations at the current level. This paper investigates potential causes of penguin decline in the Falkland Islands, drawing comparison with populations in Chile which appear to be healthy. It concludes by calling on the Falkland Islands Government to exclude large-scale commercial fishing close to penguin breeding sites.
\end{abstract}

Key words: penguins, Falkland Islands, Falklands.

\section{RESUMEN}

Las islas Falklands son un lugar importante para tres especies de pingüinos, pingüino papua (Pygoscelis papua), pingüino de penacho amarillo (Eudyptes c.chrysocome) y pingüino de Magallanes (Spheniscus magallanicus). Recientemente estas especies han disminuido $84 \%$ en estas islas. En la costa de Sudamérica los pingüinos no disminuyeron. Se sospecha que la causa es una reducción de peces y calamares debido a los barcos de pesca comercial que operan en aguas de las Islas Falklands. En 1995 el pingüino papua y el pingüino penacho amarillo terminaron sus disminuciones y ya parece que sus poblaciones están en equilibrio, pero en un número mucho mas bajo que antes que los pescadores comenzaron 20 años atrás. El pingüino de Magallanes todavía disminuye en las Islas Falklands. El pingüino de Magallanes depende más de especies de calamares y peces capturados por barcos de pesca comercial. Avisos de protección de la fauna no fueron suficientes para impedir que 1998 comenzaras exploraciones petroleras en las Islas Falklands. Tres derrames de petróleo ocurrieron en cinco meses, y cientos de pingüinos murieron. La torre de perforación se fue después de cinco meses, y no ocurrieron más derrames de petróleo. Nuevamente van a comenzar a buscar petróleo, sin mejorar la protección para la fauna. El turismo ha crecido rápidamente en las Islas Falklands, y la mayoría de los turistas llegan para ver los pingüinos. Investigaciones de poblaciones y éxito reproductivo indican que aún no hay efectos perjudiciales para los pingüinos por esta actividad. En este trabajo se investigan las causas potenciales de la disminución de pingüinos en las Islas Falklands y se hacen compariciones con poblaciones en Chile que parecen saludables.

Palabras clave: pingüinos, Islas Falklands, Malvinas. 


\section{INTRODUCTION}

The Falkland Islands lie in the south-west Atlantic, $450 \mathrm{~km}$ north east of the southern tip of South America. The archipelago is made up of over 700 hundred islands, comprising a total land area of over $12,000 \mathrm{~km}^{2}$. The irregular shape and large number of islands, gives the Falklands a very long coastline in relation to its land area, providing a wide variety of coastal habitats (Fig. 1). This varied habitat, combined with the productive waters of the Patagonian shelf, make the Falklands a good place for seabird reproduction and feeding, especially for albatross, cormorants and penguins.

Five species of penguin breed in the Falkland Islands: king penguin (Aptenodytes patagonicus, Miller 1778), gentoo penguin (Pygoscelis papua, Forster 1781), southern rockhopper penguin (Eudyptes c. chrysocome, Forster 1781), macaroni penguin (Eudyptes chrysolophus, Brandt 1837), and Magellanic penguin (Spheniscus magellanicus, Forster 1781). During the 1980s and early 1990 s populations of gentoo, southern rockhopper and Magellanic penguins declined dramatically in the Falklands. A lack of comparative data made it impossible to determine whether such declines were part of a regional trend, or whether they were due to circumstances pertaining to the Falklands. There was also a lack of basic research data with which to determine the extent to which human activities (such as commercial fishing, tourism, oil exploration and removal of eggs for human consumption) were contributing to the decline. Since the late 1980s, penguin populations around the Falklands have been studied in order to address these issues. This paper looks at the evidence of population decline in the Falklands, and investigates the role of human activities, using comparative data from South America.

\section{MATERIAL AND METHODS}

In the austral summer of 1995-1996, an islandwide penguin census of the Falkland Islands was conducted. All species were counted except for the Magellanic penguin, which was not included because of the difficulties of conducting a census on a species that nests in burrows.

For gentoo and rockhopper penguins, nest counts were made to determine the number of breeding pairs. Counts were timed to correspond with the end of the egg laying period, thereby ensuring that few pairs were still to lay, and allowing an assessment to be made of the underestimate due to pairs failing, by using failure rates during incubation from other studies. Gentoo penguins concluded their first egg-laying by the end of October 1995 . The $1995 / 96$ census counted $15 \%$ of the Gentoo population between 15th and 31st October, and the remainder between 1st November and 1st December. Because Gentoos failing early tend to re-lay, and failure rates during incubation are low (ca. $1 \%$ per week), the magnitude of any underestimates resulting from differences in

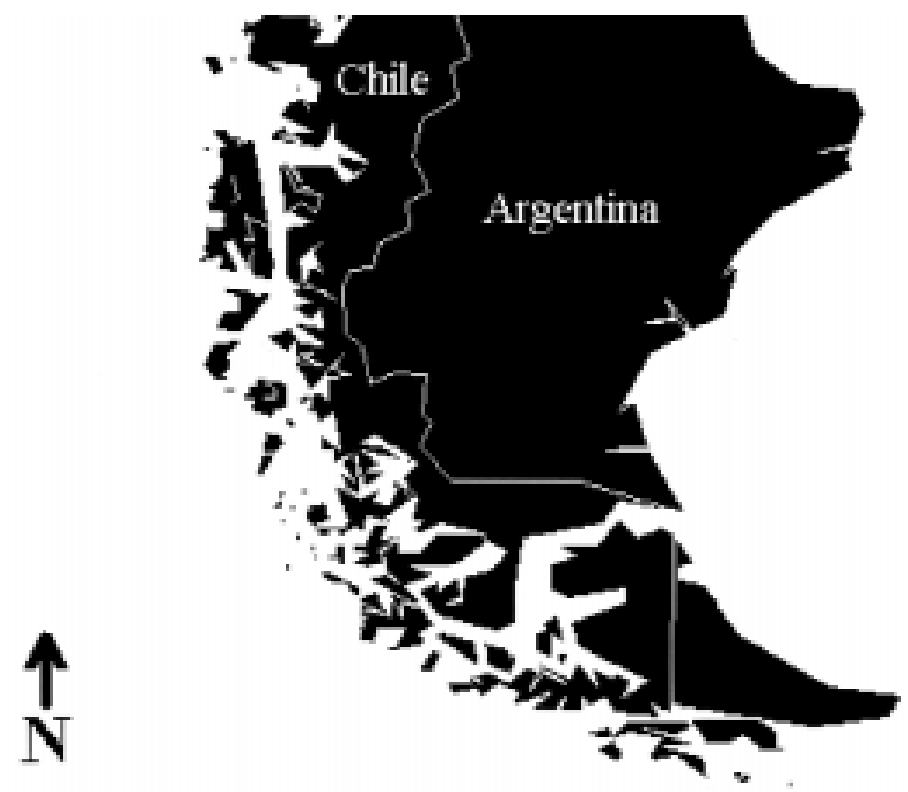

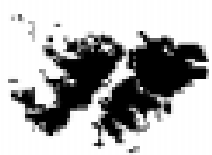

Falkland Islands

Fig. 1: Location of the Falkland Islands in relation to South America.

Ubicación de las Islas Falkland en relación a Sudamérica. 
survey dates should be well below $5 \%$. Rockhopper penguins are much more synchronous in terms of egg-laying than Gentoo penguins. Laying was concluded by mid-November 1995 , and the 1995-1996 census counted $98 \%$ of the rockhopper population between 1 st November and 1 st December (2\% between 2 nd and 18 th December). Repeated counts of rockhopper colonies in previous years showed that nest counts drop at a rate of about $3 \%$ per week for the first month after egg-laying, as a result of failed nests. It is therefore unlikely that the average underestimate of rockhopper population exceeded $10 \%$.

For most rockhopper and all gentoo breeding sites, the recorder made two separate counts of all occupied nests using a tally counter. The mean of the two counts was taken as the number of breeding pairs. Where these counts differed by more than $10 \%$, a third count was taken to give a mean of three counts. In practice this was rarely necessary, and the spread of results was usually well within plus or minus $5 \%$. However, for the very large rockhopper colonies on Steeple Jason, Grand Jason, Bird Island and Beauchene Island, direct ground counts were not possible. These sites were counted using a total of 60 randomly selected sample plots to determine the range of nesting densities, and the areas of the colonies were determined to enable estimates of total breeding pairs. A minimum of $10 \%$ and a maximum of 15 $\%$ of the total colony area was sampled at each of the sites. These measurements of area and density taken during the site visits were later compared against aerial photographs taken of the colonies. The margin of error for this methodology is greater than for direct counts, but should be within plus or minus $10 \%$.

The breeding cycle of the king penguin is different from that of gentoos and rockhoppers, with chicks over-wintering at the colony, and a complete breeding cycle lasting over a year. This tends to result in individual birds having their following breeding cycle out of phase with its predecessor; thus large chicks and eggs both occur in a colony at the same time. This complicates assessment of breeding pairs, so chick counts were taken instead. The estimation of error for chick counts is well below $5 \%$, but will under estimate the number of breeding pairs by about 20 $\%$ (Lewis-Smith \& Tallowin 1979).

Between 1989 and 2002, a total of 40 breeding sites (one king, 21 gentoo, eight rockhopper and 10 Magellanic) were counted annually in the Falklands to determine changes in population size. For king, gentoo and rockhopper penguins these counts were conducted as described above.
Because Magellanic penguins nest in burrows in the Falklands, nest counts were conducted by examining each burrow within the colony for signs of nest occupation and breeding activity. For difficult burrows the use of a video camera on a long pole was employed to determine the presence of an active nest. Each burrow occupied by a breeding pair was marked with a small spot of paint during the count to prevent doublecounting.

Annual chick counts were also made at each of the study sites prior to fledging, in order to determine annual breeding success. Breeding success was determined by conducting nest counts within the colony at the onset of incubation, as described above. Each colony was then revisited just prior to fledging, and all chicks within the colony were counted. Two counts were made using a tally counter, with a third count being made where the first two results differed by more than $10 \%$. Breeding success was taken as the mean number of chicks recorded within the colony divided by the mean number of occupied nests recorded at the start of the season (chicks per breeding pair).

For Magellanic penguins around 250 occupied burrows were also marked with names or numbers, and visited an average of three times per week from October to March, in order to record eggchick progress and to determine the causes of egg-chick loss. Eggs that failed to hatch were later examined to determine the stage of embryo development, and dead chicks were removed from the burrows for measuring and weighing, and to assess the causes of death where possible. Fledglings were weighed prior to departure from the colony, by suspending birds from a spring balance using a soft cotton loop around the legs. Some adults were marked in their burrows using red and blue animal marker crayons on long poles, so that each partner could be identified during hourly observations. These markings were placed on the throat where they were easily visible during nest inspections, and where they could not be easily removed during preening. Hourly observations recorded time spent in and away from the burrow for each partner during incubation and chick rearing.

In addition to monitoring overall population trends and breeding success, comparisons were made to determine the effects of human activity in the Falklands. Population trends and breeding success were compared for colonies that are actively promoted by the Falkland Islands Tourist Board as official tourist destinations, and for colonies that are not visited by any tourists, in order to investigate the impacts of tourism. The Falkland Islands Government also permits the 
removal of gentoo penguin eggs for human consumption. Unlike most other penguins, gentoos will readily re-lay after loosing their clutch, leading to claims by farmers that the removal of eggs does not harm the species. Comparisons of population trends and breeding success were made for colonies where eggs are harvested for human consumption, and for colonies from which no eggs are taken, in order to evaluate the impact of egging.

Each year diet samples were taken of gentoo, rockhopper and Magellanic penguins using the stomach-flushing technique described in Wilson (1984). Samples were taken during incubation and chick-rearing, from adults returning to the colony after foraging. Samples sizes varied from year to year, but average around 25 individuals per year for each species.

Stomach samples were drained and stored in jars with formaline solution or alcohol, ready for later examination. Once in the laboratory the stomach samples were rinsed with water, drained to remove any excess liquid, and weighed to determine the wet weight of food retrieved. Each sample was then divided up into its appropriate components, which were weighed individually to determine proportional dietary composition by wet weight. Fish otoliths, cephalopod beaks and crustacean carapaces (which are not easily digested) were used to aid species identification, and to estimate proportional composition. These data were then compared with fisheries catch statistics in order to determine the level of overlap between penguin diet and commercial fishing activities (Falkland Islands Government 2001). From 1998 diet sample analysis in the Falklands was taken over by Dr. A. Clausen of Falklands Conservation (Clausen 2000), although the methodology remained unchanged (Wilson 1984).

During the austral summer of 1996-1997, a penguin census was conducted in South America, in order to determine whether penguin declines in the Falklands had occurred elsewhere. It had been shown during the 1995-1996 census of the Falkland Islands that it requires little extra effort to count all penguin species during the course of such a census. The only exception was the Magellanic penguin. Its widespread, low-density distribution in burrows made it impossible to census with methods employed for surface nesting species. For this reason it was decided that the 1996-1997 census would include all South American penguins, except for those of the genus Spheniscus.

During the 1995-1996 Falkland Islands census it had been possible to conduct ground counts of incubating pairs at each of the breeding colonies, because most colonies were relatively accessible. By contrast, many of the South American colonies are remote and inaccessible, and any attempt to conduct ground counts of each and every colony would have been doomed to failure. It was therefore decided from the outset that the census would be conducted by light aircraft, thereby negating the need to get ashore at difficult and remote sites.

The location of all the Falkland Islands breeding sites had been known prior to the commencement of the 1995-1996 census, but this was certainly not the case for South America. Although data did exist for a number of known breeding sites around South America (Venegas 1984, 1991, Frere et al. 1993, Woehler 1993), it was likely that other sites existed which had not been previously recorded. This was another reason for favouring an aerial census, since it provided the opportunity to cover large areas of suitable coastline in search of previously unrecorded colonies. This reduced the margin of error that would otherwise have arisen from new sites being overlooked, however the margin of error for aerial counts was higher than for ground counts.

In order to quantify the margin of error likely to be expected from aerial counts, a number of aerial censuses were made of rockhopper colonies in the Falkland Islands for which the number of breeding pairs was also determined by ground counts. These aerial counts differed by a maximum of $14 \%$ from ground counts made of the same colony, giving a total margin of error of $\pm 20 \%$ for aerial census data.

The 1996-1997 aerial census was conducted throughout the known Eudyptes breeding ranges of Chile and Tierra del Fuego. The Atlantic coast of mainland Argentina was excluded from the census, since this coastline has been well studied, and does not hold any breeding sites for species covered by the census, except for a very small rockhopper colony on Isla Pingüino, near Puerto Deseado (Frere et al. 1993). This colony is regularly monitored as part of an ongoing research programme, and population data from their research was used in favour of duplicating results.

Since 1997 the annual monitoring of Magellanic penguins has been extended to include colonies in southern Chile, in order to compare annual population trends, breeding success, foraging behaviour and diet composition between the Falkland Islands and Chile.

\section{RESULTS}

The 1995-1996 Falkland Islands census recorded 65,000 breeding pairs of gentoo penguins at 81 
breeding sites (Fig. 2). This represents a decline of around $45 \%$ since the early 1980s (Croxall et al. 1984). A repeat census by Falklands Conservation in 2000-2001 (Clausen 2001) shows a population recovery to around 113,000 breeding pairs, equivalent to about $35 \%$ of the world population, last estimated at 320,000 breeding pairs (Woehler 1993).

The 1995-1996 Falkland Islands census recorded 297,000 breeding pairs of southern rockhopper at 36 breeding sites (Fig. 2). This represents an $88 \%$ decline since the early 1980s (Croxall et al. 1984). A repeat census by Falklands Conservation in 2000-2001 (Clausen 2001) recorded a population of 272,000 breeding pairs. The current Falklands population represents about $60 \%$ of the world population, with the remaining $40 \%$ located at 15 breeding sites in Chile and Argentina (Bingham \& Mejias 1999).

Although an island-wide census has never been conducted for Magellanic penguins, annual counts since 1989-1990 indicate that Magellanic penguins have undergone a $76 \%$ decline in the Falklands between 1989-1990 and 2001-2002 (Fig. 2). No data exists prior to 1989-1990, but since gentoo and rockhopper penguins underwent their greatest declines during the 1980 s, it is likely that the overall decline of Magellanic penguins is much greater than the $76 \%$ recorded. Unlike gentoo and rockhopper penguins, Magellanic penguins are still declining.

Gentoo penguins have averaged 0.84 chicks per breeding pair since studies began in 1990-1991 $(\mathrm{SD}=0.21, \mathrm{n}=12)$. Prior to 1993-1994 the average was 0.73 chicks per breeding pair, but between 1993-1994 and 1999-2000 the average increased to 0.99 chicks per breeding pair (Fig. 3). A Mann-Whitney U-test showed this difference to be significant at the $5 \%$ level. Gentoo populations stopped declining around 1993-1994, and by 2000-2001 they had recovered to their prefisheries level of around 115,000 breeding pairs (Bennett 1933, Croxall et al. 1984). Since then breeding success has slumped to an average of only 0.59 chicks per breeding pair, with the last two seasons data showing the lowest breeding success ever recorded.

Magellanic penguins have averaged 0.71 chicks per breeding pair since recording began in 1989$1990(\mathrm{SD}=0.25, \mathrm{n}=13)$. Prior to $1992-1993$ the average was 0.43 chicks per breeding pair, but between 1993-1994 and 1999-2000 the average increased to 0.92 chicks per breeding pair (Fig. 3). A Mann-Whitney U-test showed this difference to be significant at the $5 \%$ level. Despite this improvement in breeding success, Magellanic penguins have continued to decline in the Falkland
Islands, and over the last two seasons breeding success has averaged just 0.53 chicks per breeding pair, the lowest level since 1992-1993.

Magdalena Island and Seno Otway are the closest major Magellanic penguin colonies to the Falkland Islands with comparable breeding conditions (ie. nesting occurring in burrows as per the Falklands). Monitoring began at these two sites in 1996-1997 to provide comparison with the Falklands. Magdalena Island and Seno Otway are situated in areas where large scale commercial fishing does not occur. Commercial fishing did occur around Magdalena Island until a few years ago, since when fishing has been banned in order to protect penguin populations ( $\mathrm{Radl} \&$ Culik 1998). These colonies have shown increases in Magellanic penguin population since studies began in 1996-1997, using identical methodology to that which has shown a population decease in the Falklands.

Breeding success for Magellanic penguins has averaged 0.71 chicks per breeding pair in the Falklands (SD $=0.25, \mathrm{n}=13$ ) (Fig. 3), whilst the two Chilean sites have averaged 1.40 chicks per breeding pair $(\mathrm{SD}=0.08, \mathrm{n}=10$ ) (Fig. 4). A Mann-Whitney U-test showed these differences to be significant at the $5 \%$ level, with the lowest value for Chile being higher than the highest value for the Falklands.

Comparison shows that lower breeding success in the Falklands results from a two fold increase in nest abandonment during the incubation phase, and a two and a half fold increase in chick mortality after successful hatching (Fig. 5). This increase in chick mortality in the Falklands was due to increased levels of starvation and malnutrition. Chick mortality during hatching showed no difference between Chile and the Falklands.

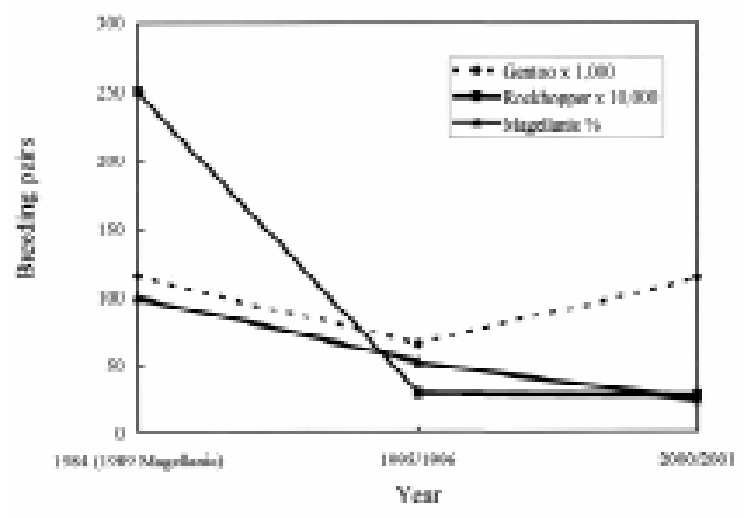

Fig. 2: Falkland Islands penguins population trends.

Tendencias poblacionales en los pingüinos de las Islas Falkland. 


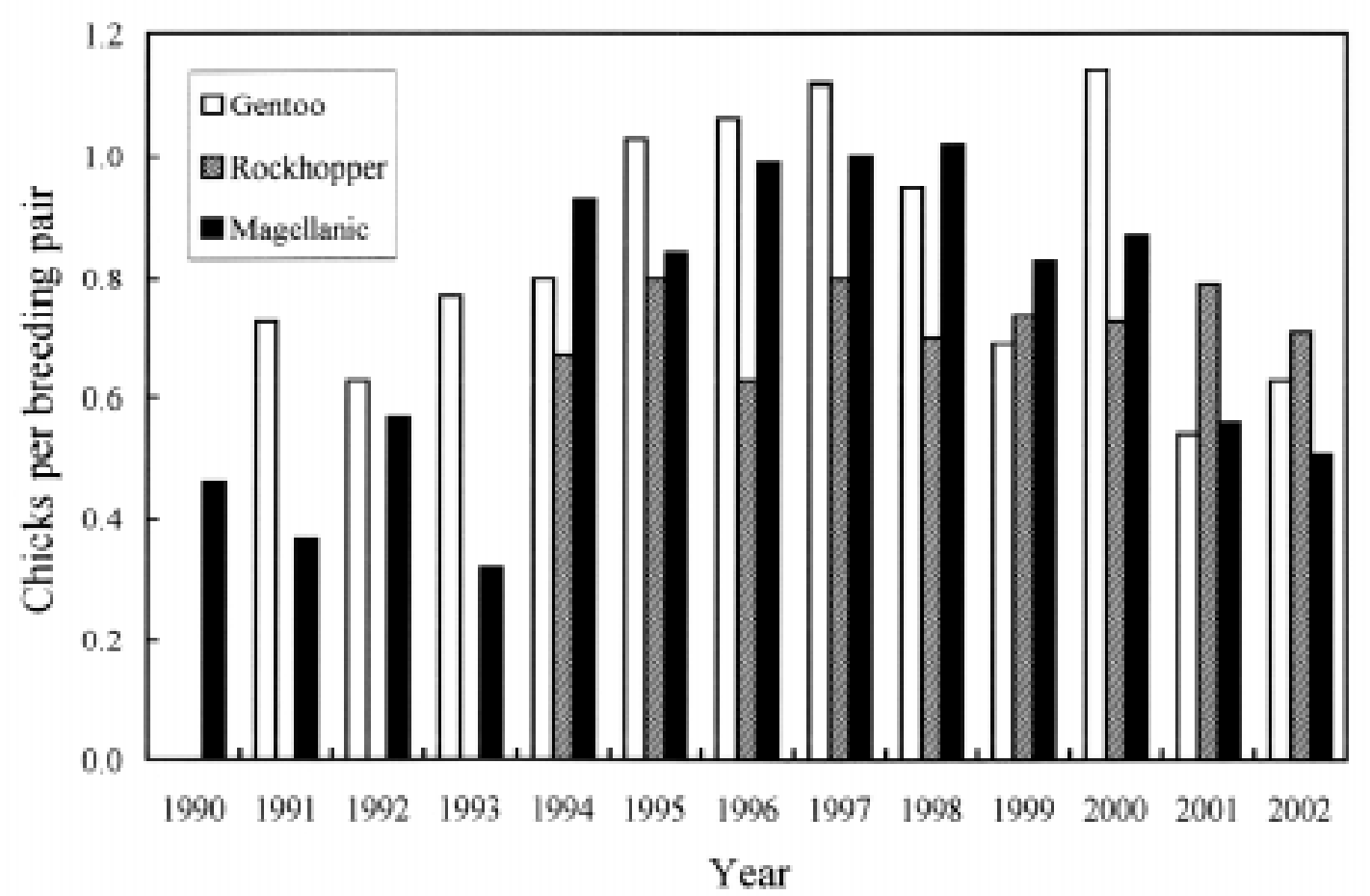

Fig. 3: Falkland Islands penguin breeding success.

Éxito reproductivo en los pingüinos de las Islas Falkland.

Fledgling weights averaged $3.3 \mathrm{~kg}$ in Chile, but only $2.7 \mathrm{~kg}$ in the Falklands, differing significantly at the $5 \%$ level using a Mann-Whitney U-test. Chicks in the Falklands fledge around 10 days later than in Chile. Mean foraging duration during chick rearing averaged $33.9 \mathrm{~h}$ in the Falklands, and $13.5 \mathrm{~h}$ in Chile, differing significantly at the 0.05 level using a Mann-Whitney U-test.

Since recording began in 1993-1994, rockhopper breeding success has remained within the range of 0.63 to 0.80 chicks per breeding pair, with an overall average of 0.73 chicks per breeding pair

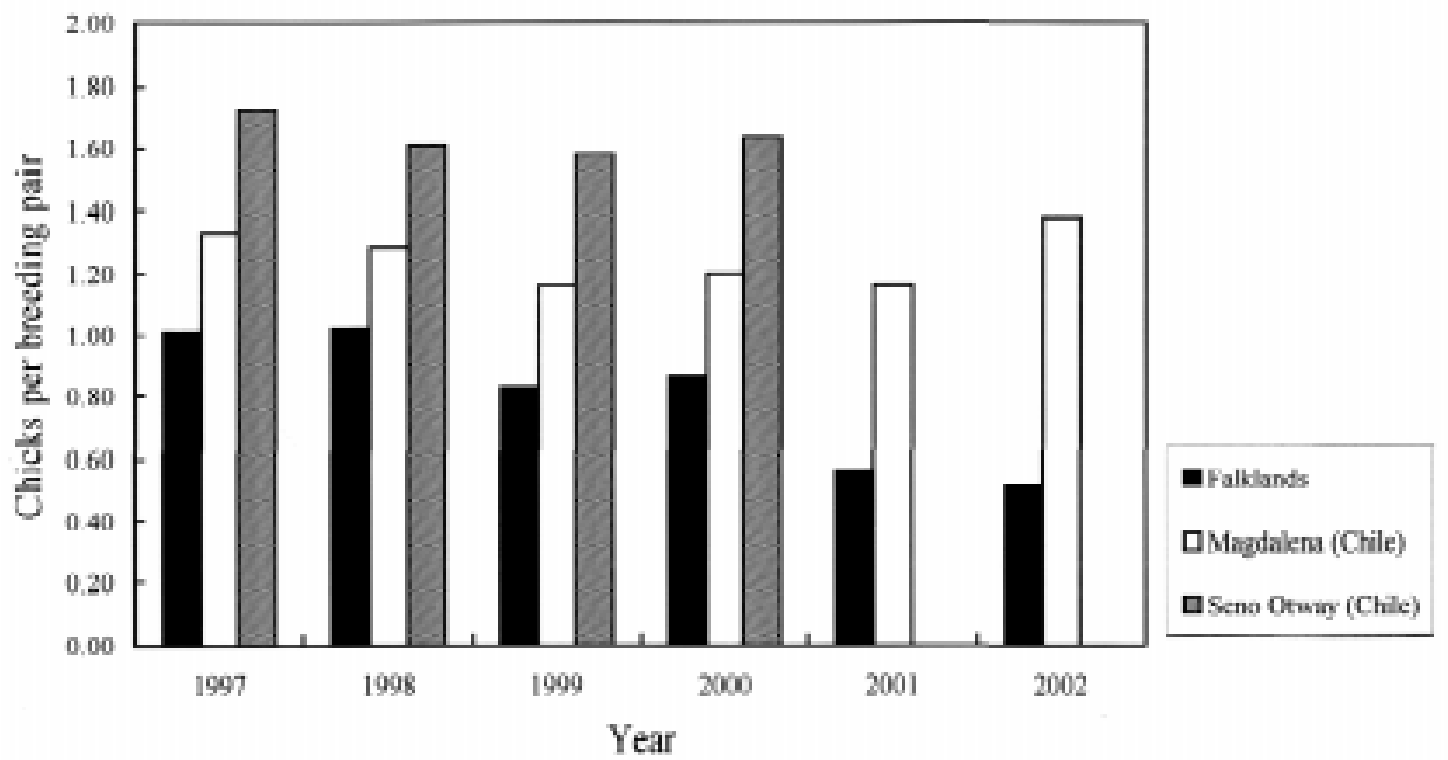

Fig. 4: Comparison of Magellanic penguin breeding success in the Falklands and Chile.

Comparación del éxito reproductivo del pingüino magellánico en las Malvinas y en Chile. 


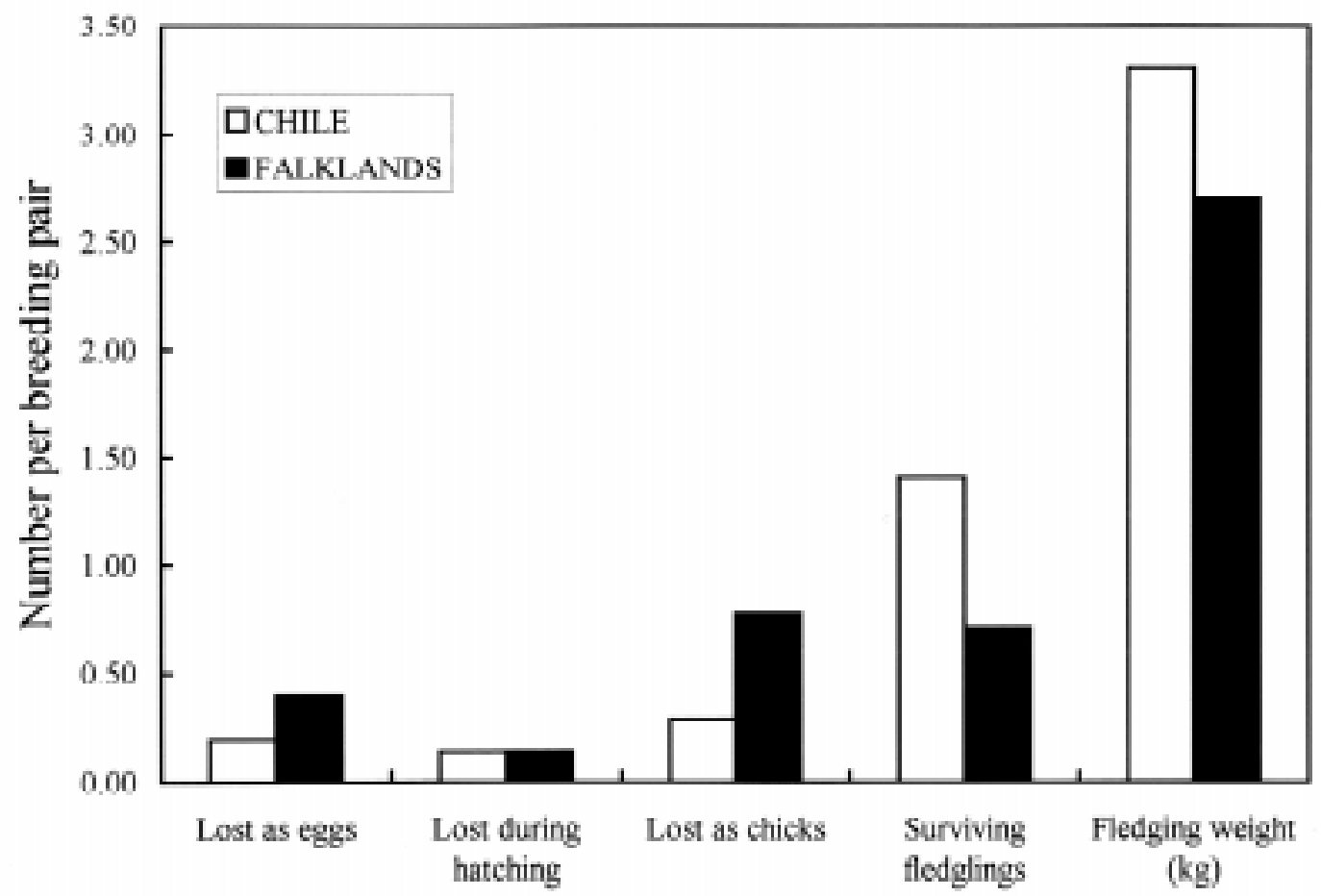

Fig. 5: Analysis of breeding failure, chick survival and fledging weights.

Análisis de fallas reproductivas, sobrevivencia de polluelos y peso de los juveniles.

$(\mathrm{SD}=0.05, \mathrm{n}=9)($ Fig. 3). A lack of data makes it impossible to determine whether rockhopper breeding success was lower prior to 1993, during their rapid population decline. However prior to 1995 virtually no juveniles were returning to undertake their annual moult, suggesting low overall recruitment.

In addition to the three main penguin species, the Falkland Islands have small numbers of king and macaroni penguins. The 1995-1996 penguin census recorded 339 king penguin chicks, which allowing for losses during incubation and chickrearing, and the staggered breeding cycle, gives an estimated Falklands population of around 400 breeding pairs. This is a tiny proportion of the estimated 1,500,000 breeding pairs world-wide (Woehler 1993). The 2000-2001 census recorded 275 chicks (Clausen 2001), a reduction of $19 \%$ since 1995-1996.

There are no macaroni penguin colonies in the Falklands, but a few macaroni penguins breed in rockhopper colonies around the islands. The total population of macaroni penguins is estimated to be no more than 50 breeding pairs (Bingham \& Mejias 1999). Two very small breeding colonies of gentoo penguins were found in South America, on Staten Island (about 30 breeding pairs) and on Hammer Island, near Ushauia (about five breeding pairs). These are the first breeding gentoos recorded for South America, but other small colonies probably await discovery.

Studies of breeding success in the Falklands showed no harmful effects from tourism or the removal of gentoo eggs for human consumption (Fig. 6). However, it should be noted that only gentoo eggs can be legally taken in the Falklands, as they are the only Falklands penguin that can relay after loosing the first clutch of eggs.

Diet sample analysis shows that gentoo, rockhopper and Magellanic penguins all rely on species of fish and squid that are currently taken commercially by the Falkland Islands' fishing industry, especially loligo squid (Loligo gahi, d'Orbigny 1835) and blue whiting (Micromesistius australis, Norman 1937) (Falkland Islands Government 1989, 2001). These species make up a small proportion of the diet of gentoos $(5.9 \%$ of observed diet) and rockhoppers (10.2\% of observed diet), but $26.5 \%$ of the observed diet of Magellanic penguins (Table 1). Magellanic penguins continue to decline, while gentoo and rockhopper penguins appear to have stopped declining.

For all three penguin species, the observed level of competition with commercial fisheries will be an under-estimate. If there were no commercial fishing activity the abundance of loligo squid and blue whiting would be considerably higher. Since 


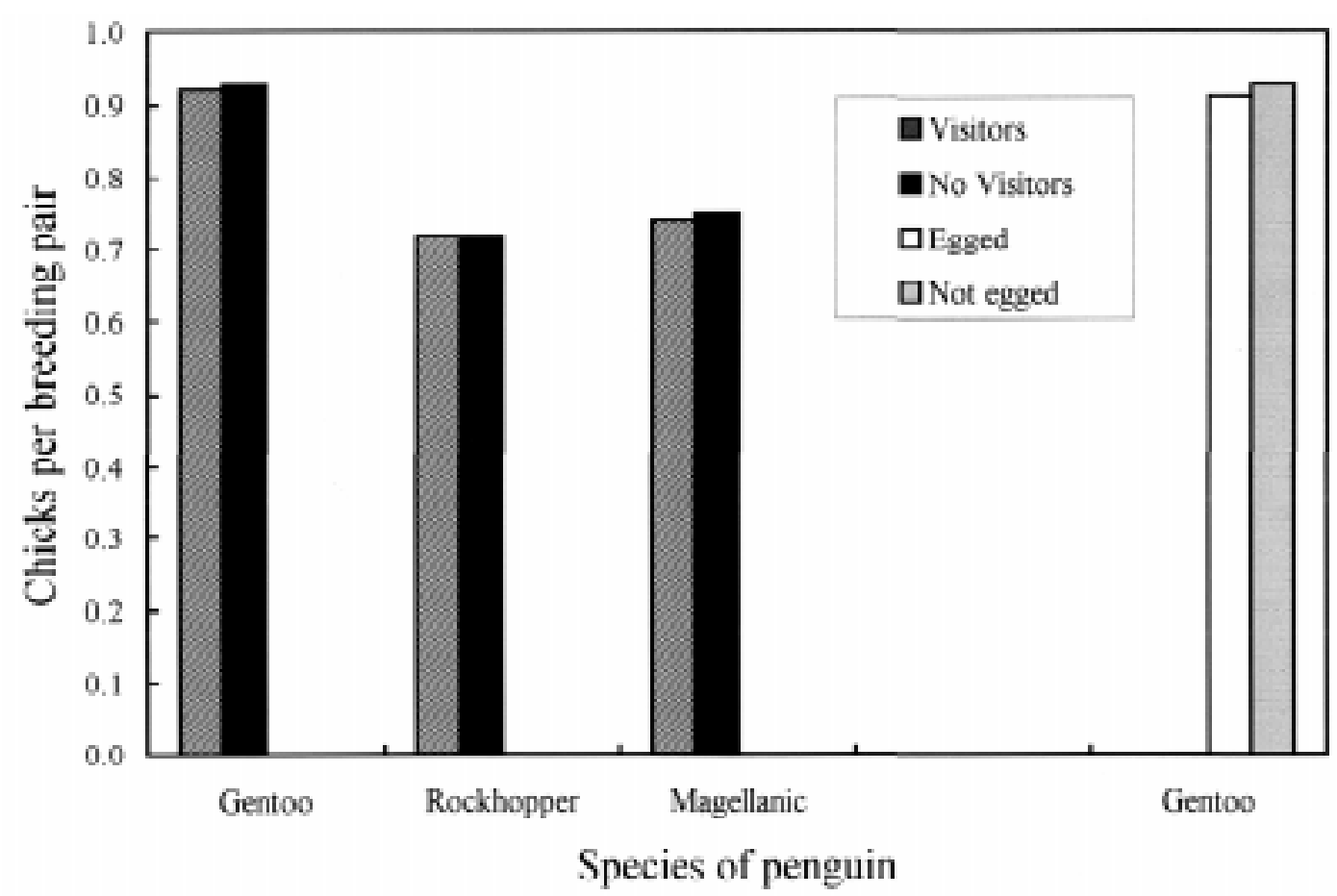

Fig. 6: Effects on breeding success of tourism and egging 1993-1994 and 2001-2002.

Efecto del turismo y la recolección de huevos sobre el éxito reproductivo 1993-1994 y 2001-2002.

penguin diet in the Falklands has only ever been studied under conditions of reduced abundance of commercially harvested species due to commercial fishing, the importance of such species to penguins under natural conditions will be greatly underestimated.

Further analysis shows that as the decline of gentoo and rockhopper penguins bottomed out in the mid 1990s, a gradual change of diet occurred, with less loligo squid being taken. Magellanic penguins have also shown a change in diet away from loligo squid, but Magellanic penguin populations have continued to decline despite this change.

\section{DISCUSSION}

The Falkland Islands is an important breeding site for gentoo, southern rockhopper and Magellanic penguins, but over the last 20 years all three have undergone population declines in the Falklands. Despite a recent recovery in the gentoo penguin population, total penguin populations in the Falklands now total just $16 \%$ of that estimated 20 years ago. This decline coincides with the development of a large scale commercial fishing industry around the Falkland Islands over the same time scale.
Southern rockhopper and Magellanic penguins are only found in the Falkland Islands and southern South America, but population declines appear to have occurred only in the Falkland Islands. Census and monitoring work in Chile indicates that southern rockhopper and Magellanic penguin populations in Chile are stable, despite their close proximity to the Falklands.

Rockhopper penguins do not change the location of their breeding sites, so prolonged occupation kills off grasses and other vegetation, leaving bare ground and lichen covered rock. In the Falkland Islands most rockhopper colonies are now found amidst much larger areas of bare ground, where vegetation has been destroyed by colonies that were once much larger. They appear rather like ponds that have dried out to leave a small puddle at the centre. These visual signs of large-scale decline are supported by census data, which shows the current rockhopper population in the Falklands to be just $11 \%$ of that recorded 20 years ago (Fig. 2).

By contrast most colonies in South America occupy the entire area laid bare, and new nesting areas can be found where vegetation has not yet been destroyed. On Staten Island (Isla de Los Estados) colonies have expanded at such a rate that large numbers of rockhoppers are nesting in dense grass which has not yet been killed off by 
nesting activity. These visual signs suggest that the South American population has remained stable, or in the case of Staten Island, undergone a rapid increase. It is possible that some emigration has occurred from the Falkland Islands to sites on coastal South America, such as Staten Island.

There is no data on rockhopper breeding success prior to 1993 , since when populations in the Falklands appear to have stopped declining, and reached equilibrium. There is however strong observational evidence that recruitment was very low in the Falklands prior to 1995. For both rockhopper and Magellanic penguins, juveniles and non-breeders return to moult at their breeding site during January and February, a time when colonies are being monitored to conduct chick counts. Virtually no rockhopper or Magellanic penguin juveniles were observed around the breeding colonies during studies prior to 1995 , suggesting very low juvenile survival, despite the fact that colonies had been observed producing fledglings during previous seasons. Since 1995 an increase in juveniles has been observed for rockhopper penguins, but not for Magellanic penguins. Colonies monitored in Chile have shown healthy numbers of juveniles each year.

Breeding success for Magellanic penguins has been recorded annually since 1989 in the Falkland Islands where large-scale commercial fishing occurs, and since 1996 for two sites in southern Chile, where large-scale commercial fishing is prohibited in order to protect penguins. Breeding success in the Falkland Islands has averaged 0.71 chicks per breeding pair (Fig. 3), whilst the average for the two Chilean colonies has been 1.40 chicks per breeding pair (Fig. 4). Large variations in breeding success are usually associated with changes in food availability (Boersma et al. 1990), and for the Falklands the main factor influencing breeding success and recruitment is assumed to be local food supply (Putz et al. 2001).

Low breeding success in the Falklands results from greater nest abandonment during egg incubation, and higher chick mortality resulting from starvation and malnutrition (Fig. 5). Surviving chicks in the Falkland Islands are of poor body condition and low weight at the time of fledging (average $2.7 \mathrm{~kg}$ ) compared to Chile (average $3.3 \mathrm{~kg}$ ). This suggests that not only do fewer chicks fledge in the Falklands, but that fledglings also have a lower chance of surviving their first year by virtue of being less well nourished. Comparison of juvenile numbers returning to their natal colony to moult support this theory. On Magdalena Island over four thousand juveniles are counted on the beach each year, whilst in the Falkland Islands very few juveniles are ever seen.
Gentoo, rockhopper and Magellanic penguins all compete directly for loligo squid (Loligo gahi) with the Falkland Islands fishing industry (Putz et al. 2001). These penguins also take blue whiting (Micromesistius australis) which is the main fish species targeted by the Falkland Islands fishing industry. Dietary overlap for commercially taken species is greatest for Magellanic penguins which are still declining rapidly, less for rockhopper penguins which have levelled off at around $11 \%$ of their pre commercial fishing population, and lowest for gentoo penguins which have recovered following an initial decline.

Over the last 10 years, the Falklands have experienced dietary changes in all three penguins away from Loligo gahi. Putz (2001) suggests that these dietary changes have been forced by reduced abundance of Loligo gahi. These changes may be harmful in terms of chick survival, since lobster krill, (Munida gregaria, Fabricius 1793), which now makes up one fifth of Magellanic penguin diet in the Falklands, is not easily digested by Magellanic penguin chicks (Thompson 1993). The theory that Magellanic penguins prefer not to take Munida gregaria if more suitable prey are available, is supported by diet sample studies in Chile. Magellanic penguins at the two Chilean study sites show a complete lack of Munida gregaria in their diet, even though Munida gregaria are present in great abundance, forming a major part of the diet of king cormorants nesting on nearby Marta Island (Radl \& Culik 1998).

Not only does the removal of preferred prey force penguins to feed their chicks less favourable species, but it can also lead to greater foraging duration, with chicks receiving less food (Radl \& Culik 1998). This increase in foraging duration is evident around the Falklands.

At the two Chilean study sites, where largescale commercial fishing is no longer permitted, Magellanic penguins average $13.5 \mathrm{~h}$ to return with food for their chicks (Radl \& Culik 1998). In the Falkland Islands, foraging trip duration averages $33.9 \mathrm{~h}$. This huge increase in foraging duration coincides with a $50 \%$ reduction in breeding success, higher chick starvation, lower fledging weight, and a substantial reduction in juvenile survival, compared to populations in Chile.

Reproductive success depends on food availability (Crawford \& Dyer 1995), and competition for food with commercial fisheries is a recognised cause of population decline in other regions (Brown \& Nettleship 1984, Duffy et al. 1987, Culik \& Luna Jorquera 1997). Breeding success and fledging weights are recognised bioindicators for monitoring the marine 
environment and marine food supplies (Cairns 1987, Furness \& Camphuysen 1997), and Magellanic penguins suggest that the marine environment around the Falkland Islands may be in poor health.

Prior to 1988 fishing around the Falkland Islands was intensive and totally unregulated, threatening fish and squid stocks (Patterson 1987). No catch data or diet sample data exists for this period, during which huge penguin population declines occurred. Following a mass starvation of penguins in 1986, when many rockhopper colonies lost over half their adult population (Keymer et al. 2001), it was agreed that commercial fishing around the Falklands needed to be regulated. This regulation was introduced in 1988, since when catch rates have gradually been reduced by controlling the number of boats licensed to fish (Falkland Islands Government 1989, 2001).

For squid, the catch rate per unit effort of fishing vessels is now monitored on a daily basis to determine when the target of $60 \%$ biomass has been removed each year. The remaining $40 \%$ biomass is deemed by the Falkland Islands Government to be adequate as prey for seabirds and marine mammals, and as breeding stock for the following season. Whilst this may ensure sustainable use of stocks as a financial resource, it seems unreasonable to suppose that $60 \%$ of the biomass can be removed prior to the breeding season of seabirds and marine mammals, without having an impact on those species which rely on such prey for successful breeding.

Diet sample analysis shows that there is competition between penguins and commercial fisheries for loligo squid (Loligo gahi) (Putz et al. 2001) and potential competition for blue whiting (Micromesistius australis) (Table 1). Since diet samples have only ever been taken in the presence of commercial fishing activities, the proportion of commercially harvested species found in penguin diet will be greatly reduced. Diet analysis

TABLE 1

Diet of three species of penguins in the Falkand Islands. Data for each prey category correspond to the percentage of weight out of the total stomach content. The total number of stomachs examined is indicated in parentheses for each species

Dieta de tres especies de pingüinos en las Islas Malvinas. Para cada presa se indica el porcentaje del peso en relación al contenido estomacal total. Para cada especie se indica el número total de estómagos examinados

\begin{tabular}{|c|c|c|c|}
\hline Prey item & $\begin{array}{c}\text { Gentoo } \\
(\mathrm{n}=238)\end{array}$ & $\begin{array}{l}\text { Rockhopper } \\
\quad(\mathrm{n}=187)\end{array}$ & $\begin{array}{c}\text { Magellanic } \\
(\mathrm{n}=297)\end{array}$ \\
\hline Squid & 12 & 27 & 41 \\
\hline Loligo gahi & 5.40 & 7.02 & 18.45 \\
\hline Gonatus antarcticus & 5.04 & 15.66 & 20.50 \\
\hline Moroteuthis ingens & 0.12 & 0 & 0.41 \\
\hline Sepiola & 0.72 & 0 & 0 \\
\hline Octopod & 0.72 & 4.05 & 0.82 \\
\hline Onychoteuthid & 0 & 0.27 & 0.41 \\
\hline Ommastrephes & 0 & 0 & 0.41 \\
\hline Fish & 54 & 23 & 40 \\
\hline Sprattus fuegensis & 9.18 & 9.89 & 15.60 \\
\hline Micromesistius australis & 0.54 & 3.22 & 8.00 \\
\hline Thysanopsetta naresi & 1.62 & 0 & 0 \\
\hline Agonopsis chiloensis & 0.54 & 4.37 & 2.40 \\
\hline Eleginops maclovinus & 0 & 3.22 & 0 \\
\hline Patagonotothen & 18.36 & 2.30 & 0.40 \\
\hline Nototheniodei & 10.80 & 0 & 13.60 \\
\hline Gadiformes & 6.48 & 0 & 0 \\
\hline Perciformes & 5.94 & 0 & 0 \\
\hline Raja & 0.54 & 0 & 0 \\
\hline Crustaceans & 34 & 50 & 19 \\
\hline Munida gregaria & 33.66 & 10.00 & 18.43 \\
\hline Themisto gaudichaudi & 0.34 & 1.50 & 0.57 \\
\hline Euphausia & 0 & 33.50 & 0 \\
\hline Amphipoda & 0 & 5.00 & 0 \\
\hline
\end{tabular}


will therefore greatly under-estimate the level of competition between penguins and commercial fisheries.

Any competition for food is likely to be exacerbated by the fact that the commercial fishing season runs until the end of October, when penguins and other seabirds begin breeding. Since stocks are managed by recording the daily decline of catch per unit effort, it stands to reason that penguins will also encounter this decline in catch per unit effort as they enter their breeding phase.

Breeding places great demands on adult penguins to find sufficient food for themselves and their chicks. Each adult must first catch sufficient food for its own needs, and a surplus for its chicks, at a time when its foraging range is greatly reduced by the need to return to the nest. A reduction in food abundance can therefore lead to greater foraging duration, less food being brought back to chicks, and reduced chick survival.

It is probable that the rapid penguin declines observed in the Falklands during the 1980s were a result of uncontrolled commercial fishing. Elephant seals and southern sea lions, which also feed on species taken by the commercial fishing industry, also underwent huge population declines in the Falklands during the same period (Strange 1992, Thompson \& Duck 1996, Galimberti 2000). As is the case for penguins, these species also occur in South America where no such declines occurred. King penguins and fur seals which feed on prey not commercially harvested, increased in population around the Falklands over the same period.

During the late 1970s and early 1980s, fish and squid stocks were heavily fished without any monitoring or control. In 1986 a lack of food led to mass starvation of adult penguins, and public concern called for controls over commercial fishing. Following the establishment of a regulatory body in 1988, the effects of overfishing have been greatly mitigated through reduction of fishing effort and control of species taken.

Chick and juvenile survival have shown some signs of improvement, and gentoo and rockhopper populations have stopped declining. These populations appear to have reached equilibrium with the current fishing regime, albeit at a much lower level than prior to the 1980s. Magellanic penguins have continued to decline however, and it is likely that their greater dependence on species which are still commercially harvested is a major factor.

Concerns about the removal of gentoo penguin eggs for human consumption were not borne out by the data, which suggest little effect on breeding success. Unlike most other penguins, gentoos have the ability to relay within a few days of loosing their clutch. This enables them to rear chicks successfully after losing their first brood. Although egging could hardly be advocated by any conservationist, in the Falklands it is a tradition which is gradually dying out, due to an improved infra-structure that allows people in remote areas to purchase a wider range of food items. Conservationists have taken the view that it is preferable to let the tradition die a natural death, rather than risk a resurgence by threatening people's right to continue the practice.

Tourism is another potential cause for concern. The Falkland Islands are now one of the world's most popular destinations for penguin spotters, and this growing tourist industry is a potential threat to Falklands penguins. The Falkland Islands received around 35,000 visitors during the 20012002 season (Fowler 2002).

Over recent years a number of scientific reports have demonstrated that even well-behaved visitors can cause stress and increased heart-rate in penguins and seabirds, but these factors are not necessarily harmful to the bird or its fecundity. Seabirds are subjected to varying levels of stress in their natural environment, so it was important to monitor the effects of tourism in its wider perspective, by conducting long-term studies of population trends and breeding success. Breeding success in particular provides a useful measure of visitor disturbance. Careless visitors have the potential to disturb breeding penguins in a number of ways: (1) incubating birds may be frightened away allowing predators to take eggs or young, (2) raised metabolic rates brought on by stress may lead to greater food requirement, (3) natural behaviour, such as courtship or the feeding of young, may be disrupted, (4) adults could be scared away completely, causing them to abandon eggs or young, (5) severe disturbance could lead to adults or young being killed or injured, and (6) birds that live in burrows may be killed if the burrow collapses under human weight.

These potential consequences of disturbance should all lead to reduced breeding success if they are occurring at a significant level, however studies of penguin breeding success in the Falklands and southern Chile show no harmful effects from tourism so far. Other penguin studies have reached similar conclusions (Cobley \& Shears 1999).

Ecotourism undoubtedly has a number of benefits. It provides wildlife with a commercial value, giving support for its protection within the commercial sector. It also educates and entertains the people who see the wildlife, raising awareness 
and gathering support for wildlife protection within the community as a whole. It is difficult to provide strong argument for wildlife protection unless people can relate to wildlife on a personal level. It is therefore important to promote ecotourism, whilst at the same time ensuring that such tourism does not damage the wildlife resources that people come to see.

There are clearly a number of threats facing penguin populations in the Falkland Islands, but penguin populations appear very robust to disturbance and moderate levels of exploitation on land. Major changes to the landscape brought about by livestock, the removal of eggs for food, and exploitation as a resource for tourism, all appear to have had low impact on penguin populations in the Falklands. Marine pollution around the Falklands has so far been limited to a spate of oil spills that occurred during drilling operations in 1998, and high levels of cadmium common to the Antarctic region in general, that may be due to natural factors (Keymer et al. 2001). The only major predators of penguins, southern sealions, have suffered a $97 \%$ decline in the Falklands (Thompson \& Duck 1996) making them an unlikely cause of penguin decline.

Even in a healthy population, starvation is the main cause of chick mortality for Magellanic penguins (Scolaro 1990, Boersma 1991*), and in the Falkland Islands low breeding success, high chick mortality, low fledging weight and low recruitment are largely due to low food supply (Putz et al. 2001). On at least one occasion this low food supply has also led to mass starvation of adult penguins (Keymer et al. 2001).

Whilst it is unrealistic to expect the Falkland Islands Government to halt commercial fishing activity, which is a major source of revenue to the islands, minor changes could be adopted which would mitigate the effects of commercial fishing on penguin populations, without greatly effecting revenue. At present commercial fishing vessels are permitted to fish within $5 \mathrm{~km}$ ( 3 miles) of the coastline, even where penguin breeding sites are located. It was proposed at the Spheniscus Penguin Conservation Workshop (September 2000, Chile) that fishing vessels in the Falkland Islands should be excluded from within $48 \mathrm{~km}$ (30 miles) of penguin breeding sites during the breeding season. Such measures would protect feeding areas within

* BOERSMA PD (1991) Asynchronous hatching and food allocation in the Magellanic penguin. Acta XX Congressus Internationalis Ornithologici: 961-973. the penguins' daily foraging range, whilst reducing the total area available to fishing vessels by just $4 \%$.

Satellite tracking has shown that around the Falkland Islands, Magellanic penguins have a mean foraging range of about $16 \mathrm{~km}$ during incubation, and $7 \mathrm{~km}$ during chick rearing, with a maximum distance of $39 \mathrm{~km}$ being recorded during chick rearing. Gentoo penguins have a mean foraging range of $6 \mathrm{~km}$, with a maximum of less than $25 \mathrm{~km}$ being recorded (Boersma et al. 2001). These foraging distances lie well within the 48 $\mathrm{km}$ (30 mile) exclusion zone requested at the Spheniscus Penguin Conservation Workshop. Rockhopper penguins were recorded foraging outside the requested exclusion zone, with short foraging trips averaging less than $6 \mathrm{~km}$, being supplemented by long distance foraging trips of well over $100 \mathrm{~km}$. Even so rockhoppers made more use of inshore waters during the critical chick-rearing stage (Boersma et al. 2001).

Magellanic penguins fitted with time-depth recorders at the two Chilean study sites showed similar results, with foraging beginning at around $7 \mathrm{~km}$ from the breeding site. Mean foraging range was $25 \mathrm{~km}$, and maximum foraging ranges for the two sites were $33 \mathrm{~km}$ (Seno Otway) and $47 \mathrm{~km}$ (Magdalena Island) (Radl \& Culik 1998).

Inshore fishing around the Falklands has a negative impact on gentoo, rockhopper and Magellanic penguins (Boersma et al. 2001). It is therefore probable that if a fishing exclusion zone were established around penguin breeding sites in the Falkland Islands, as has been done around Magdalena Island in Chile, that this would allow an increase in food availability within the penguins' foraging range. This in turn should lead to a decrease in foraging duration, an increase in food brought back to chicks, and an increase in chick survival and fledging weights, as has been observed since the exclusion of large-scale commercial fishing from around Magdalena Island. The exclusion of fishing would only be required just prior to and during the breeding season, and it might also help protect Falklands penguins from their other major threat, marine pollution.

During 1998 an oil rig was sent to the Falkland Islands to look for oil. During the five months of operation three separate oil spills occurred killing hundreds of penguins. It is unlikely that the oil came from the rig itself, which claimed never to have found oil in commercially viable quantities. The oil is presumed to have come from oil rig supply vessels operating in Falkland waters at the time. No further oil spills have occurred since the oil rig and its supply vessels left the Falklands. 
In 1995 the United Kingdom, Argentina and the Falkland Islands set aside a Special Area of Cooperation for future oil exploration and development, so there is little doubt that oil exploration around the Falklands will recommence in the near future. Unless environmental protection is greatly improved, it is probable that many more penguins will die in unnecessary oil spills, as happens each year along coastal Argentina.

The Falkland Islands are an internationally important breeding site for penguins, and it is vital that the Falkland Islands Government accept their responsibility to protect this natural resource. Rockhopper penguins now number just $11 \%$ of the population recorded in the Falklands 18 years ago, and they are now classified as "vulnerable" under International Union for Conservation of Nature (IUCN) guidelines. Magellanic penguins have undergone a similar magnitude of decline, and are still declining. Sea lions and elephant seals have also undergone major declines since the establishment of a commercial fishing industry in the Falklands.

It is very difficult to prove the link between the decline of these species, and the establishment of large-scale commercial fishing around the Falklands, just as it is difficult to prove links between smoking and individual cases of heart disease or lung cancer. However, many take the view that for non-target species, and especially protected species such as penguins, the burden of proof for no harm lies with the exploiter (Boersma et al. 2001).

On a per capita basis, the Falklands is one of the wealthiest places on earth, with an annual government income of over US $\$ 30,000$ for every person living in the islands. As such there is no reason why financial interests should outweigh the need for adequate protection of Falklands wildlife.

\section{ACKNOWLEDGEMENTS}

Thanks go to the Environmental Research Unit, Falklands Conservation, Falkland Islands Fisheries Department, Corporación Nacional Forestal (Chile), Fundación Otway (Chile), Aerovias DAP, Arne Radl, the rangers of Magdalena Island, and the crews of "Melinka", "Tierra Australis", "Hundy" and "Don Jorge" for logistical support, and to research assistants Nidia Mendez and Cici Legoe. Thanks also to the Conservation \& Research Foundation (Connecticut, USA), the PADI Foundation (Beverly Hills, USA), Fauna and Flora International (UK), and the Darwin Initiative (British Government) for providing funding.

\section{LITERATURE CITED}

BENNETT AG (1933) The penguin population of the Falkland Islands in 1932/33. Government Press, Falkland Islands. 4 pp.

BINGHAM M \& E MEJÍAS (1999) Penguins of the Magellan region. Scientia Marina 63 (Suplement) 1: 485-493.

BOERSMA PD, DL STOKES \& PM YORIO (1990) Reproductive variability and historical change of Magellanic penguins at Punta Tombo, Argentina. In: Davis LS \& JT Darby (eds) Penguin biology: 15-43. Academic Press, San Diego, California.

BOERSMA PD, DL STOKES \& IJ STRANGE (2001) Tracking breeding penguins at New Island South Reserve: an overview of work carried out between 1997 and 2001. New Island South Conservation Trust Supplement 2, Stanley, Falkland Islands. 4 pp.

BROWN RG \& DN NETTLESHIP (1984) Capelin and seabirds in the Northwest Atlantic. In: Nettleship DN, GA Sanger \& PF Springer (eds) Marine birds: their feeding ecology and commercial fisheries relationships: 184-195. Canadian Wildlife Services Publication, Ottawa, Canada.

CAIRNS DK (1987) Seabirds as indicators of marine food supplies. Biological Oceanography 5: 261-271

CLAUSEN A (2000) Falkland Islands Seabird Monitoring Programme Report. Falklands Conservation Report SMP8, Stanley, Falkland Islands. 56 pp.

CLAUSEN A (2001) Falkland Islands Penguin Census 2000/01. Falklands Conservation Report, Stanley, Falkland Islands. 27 pp.

COBLEY ND \& JR SHEARS (1999) Breeding performance of gentoo penguins at a colony exposed to high levels of human disturbance. Polar Biology 21: 355360.

CRAWFORD RJM \& BM DYER (1995) Responses by four seabird species to a fluctuating availability of Cape anchovy Engraulis capensis off South Africa. Ibis 137: 329-339.

CROXALL JP, MCINNES SJ \& PRINCE PA (1984) The status and conservation of seabirds at the Falkland Islands. In: Croxall JP, PGH Evans \& RW Schreiber (eds) Status and conservation of the world's seabirds: 271-291. ICBP Technical Publication No.2, ICBP, Cambridge, United Kingdom.

CULIK BM \& G LUNA-JORQUERA (1997) Satellite tracking of Humboldt penguins (Spheniscus humboldti) in northern Chile. Marine Biology 128 : 547-556.

DUFFY DC, RP WILSON, RE RICKLEFS, SC BRONI \& H VELDHUIS (1987) Penguins and purse seiners: competition or coexistence? National Geographic Research 3: 480-488.

FALKLAND ISLANDS GOVERNMENT (1989) Falkland Islands interim conservation and management zone fisheries report '87/88. Falkland Islands Government Report, Falkland Islands. 74 pp.

FALKLAND ISLANDS GOVERNMENT (2001) Fisheries Department Fisheries Statistics, Volume 5, 2000. FIG Fisheries Department, Stanley, Falkland Islands. 68 pp. 
FOWLER J (2002) Review of trends and changes in Falklands Tourism 1995-2001. Falkland Islands Tourist Board, Stanley, Falkland Islands. 46 pp.

FRERE E, M GANDINI, P GANDINI, T HOLIK, V LICHTSCHEIN \& MO DAY (1993) Variación anual en el número de adultos reproductivos en una nueva colonia de pingüino penacho amarillo en Isla Pingüino (Santa Cruz, Argentina). Hornero 13: 293-294.

FURNESS RW \& CJ CAMPHUYSEN (1997) Seabirds as monitors of the marine environment. ICES Journal of Marine Science 54: 726-737.

GALIMBERTI F (2000) Elephant seals of the Falklands. Elephant Seal Research Group report, Milano, Italy. $31 \mathrm{pp}$.

KEYMER IF, HM MALCOLM, A HUNT \& DT HORSLEY (2001) Health evaluation of penguins following mortality in the Falklands. Diseases of Aquatic Organisms 45: 159-169.

LEWIS-SMITH RI \& JRB TALLOWIN (1979) The distribution and size of king penguin rookeries on South Georgia. British Antarctic Survey Bulletin 49: 259-276.

PATTERSON KR (1987) Fishy events in the Falkland Islands. New Scientist 1562: 44-48.

PUTZ K, RJ INGHAM, JG SMITH \& JP CROXHALL (2001) Population trends, breeding success and diet composition of gentoo, Magellanic and rockhopper penguins in the Falkland Islands. Polar Biology 24: 793-807.

RADL A \& BM CULIK (1998) Foraging behaviour and reproductive success in Magellanic penguins: a comparative study of two colonies in southern Chile. Marine Biology 133: 381-393.

Associate Editor: P. Marquet

Received October 26, 2001; accepted July 8, 2002
SCOLARO JA (1990) Effects of nest density on breeding success in a colony of Magellanic penguins (Spheniscus magellanicus). Colonial Waterbirds 13: 41-49.

STRANGE IJ (1992) Wildlife of the Falkland Islands and South Georgia. Harper Collins, London, United Kingdom. 188 pp.

THOMPSON D \& CD DUCK (1996) Southern sea lions in the Falkland Islands. Sea Mammal Research Unit Report, Cambridge, United Kingdom. 48 pp.

THOMPSON KR (1993) Variation in Magellanic penguin diet in the Falkland Islands. Marine Ornithology 21: 57-67.

VENEGAS C (1984) Estado de las poblaciones de pingüino de penacho amarillo y macaroni en la Isla Noir, Chile. Informe Instituto de la Patagonia 33, Punta Arenas, Chile. 25 pp.

VENEGAS C (1991) Estudio de cuantificación poblacional de pingüinos crestados en Isla Recalada. Informe Instituto de la Patagonia 55, Punta Arenas, Chile. 27 pp.

WILSON RP (1984) An improved stomach pump for penguins and other seabirds. Journal of Field Ornithology 55: 9-12.

WOEHLER EJ (1993) The distribution and abundance of Antarctic and subantarctic penguins. SCAR, Cambridge, United Kingdom. 76 pp. 